\title{
Development Strategy of the New Normal Ecotourism Bussiness on Hutan Bambu Alu in Polewali Mandar, Indonesia
}

\author{
Ritabulan ${ }^{1}$, Muhammad Rizky Prawira $^{2}$, Nuraeni $^{3}$ and Sitti Hadijah ${ }^{4}$ \\ \{ritabulan@unsulbar.ac.id ${ }^{1}$, muhammadrizkyprawira@unsulbar.ac.id ${ }^{2}$, \\ nuraeni@unsulbar.ac.id ${ }^{3}$, hadijah@unsulbar.ac.id ${ }^{4}$ \}
}

Forestry Study Program, Universitas Sulawesi Barat, Majene, Indonesia ${ }^{1}$, International Relations Study Program, Universitas Sulawesi Barat, Majene, Indonesia ${ }^{2}$, Accounting Study Program, Universitas Sulawesi Barat, Majene, Indonesia ${ }^{3-4}$

\begin{abstract}
The covid-19 pandemic affects almost all areas of life, including tourism. Hutan Bambu Alu is one of the tourist destinations in West Sulawesi which is also affected by the covid-19 pandemic. This study aimed to identify the potential supply and demand for ecotourism in the area of Hutan Bambu Alu and formulate a strategy for developing an ecotourism business in the area of Hutan Bambu Alu in accordance with the concept of the new normal tourism. This study used an analysis approach based on the development criteria of Dirjen PHKA 2003 and SWOT analysis. The results showed that the main supply and support element of the Hutan Bambu Alu ecotourism business had a high category so that it was feasible and suitable to be developed into a new normal ecotourism business. The selected strategy for developing a new normal ecotourism business is to minimize weaknesses to take advantage of opportunities.
\end{abstract}

Keywords: pandemic covid-19, ecotourism, new normal, Hutan Bambu Alu, SWOT analysis

\section{Introduction}

The covid-19 pandemic affects almost all areas of life, including tourism. The Minister of Tourism dan Creative Economy revealed that cumulatively from January to March 2020, the number of foreign tourists visiting to Indonesia reached 2.61 million visits or decreased by 30.62 percent compared to the number of foreign tourists visiting in the same period in 2019 which totaled 3.76 million visits [1][1].

Hutan Bambu Alu (Alu Bamboo Forest) is one of the tourist destinations in West Sulawesi which is also affected by the covid-19 pandemic. Hutan Bambu Alu area has several potential objects of natural mountain attraction. This area is traversed by the Mandar River (Sungai Mandar) as the main river in the Mandar Watershed (Daerah Aliran Sungai Mandar/DAS Mandar) in West Sulawesi. There were several tourism events that are packaged in the form of cultural performances have been held at the Hutan Bambu Alu, including the holding of the Mandar Traditional wedding procession and Festival Sungai Mandar or FSM (the Mandar River Festival) in 2018 and 2019. Currently the Hutan Bambu Alu has also entered its 2nd year in the Partnership Village Development Programme (Program 
Pengembangan Desa Mitra/PPDM) which is facilitated through community service activities by Universitas Sulawesi Barat [2].

The development of Hutan Bambu Alu is one of the ecotourism areas in West Sulawesi due to the important position of this area as an integral part of the DAS Mandar area. Ecotourism development that holds the principles of ecotourism such as natural resourses conservation and increasing the community welfare. Ecotourism as a potential tourism development model in preserving natural resources and supporting the economic improvement process of local communities [3]. In its development, the pandemic has an impact on the need to create a new normal ecotourism development model that emphasizes the health and safety factors of visitors of the Hutan Bambu Alu. Muntasib (2020) argued that this pandemic condition is an opportunity and opportunity for us to return to ecotourism because in ecotourism, apart from its economy, ecotourism also educates people in the context of protecting nature [4].

This study aimed to identified the potential of supply and demand for ecotourism on Hutan Bambu Alu and to formulated the strategy for developing an ecotourism business on Hutan Bambu Alu in accordance with the concept of the new normal tourism.

\section{Method}

\subsection{Location and Time}

This research was conducted on the Hutan Bambu Alu area in Alu Village, Alu Sub District, Polman Regency in West Sulawesi Province, Indonesia. The research was conducted for 6 months from February to July 2020.

\subsection{Material}

The materials used in data collection were questionnaires, interview guides, maps of the area and the data of managers, communities and visitors. The tools used were writing instruments, camera, Global Position System (GPS) and assessment manual of Analysis of the Area on the Object of Natural Tourism Attraction (Analisis Daerah Operasi - Obyek Daya Tarik Wisata Alam/ADO-ODTWA) [5].

\subsection{Type of Data}

The data collected consists of primary and secondary data. Primary data consists of the potential value of supply and demand for ecotourism. Supply potential includes the value of attractiveness (natural beauty, uniqueness of natural resources, the many types of natural resources that stand out, the integrity of natural resources, sensitivity of natural resources, types of natural tourism activities, location cleanliness, and area security) and value of supporting elements (accessibility, conditions around the area, facilities and infrastructure). The data of supply potential consists of the visitor characteristics and preferences. Secondary data consists of a map of the area, a map of tourism development, and the socio-economic conditions of the community around the area of Hutan Bambu Alu.

\subsection{Data Collection}


Data collection was carried out through observation, in-depth and structured interviews, and literature review. Observations are made by directly observing the conditions of the attraction and supporting elements of ecotourism in the Hutan Bambu Alu area. In-depth interviews were conducted with the key informants who were selected based on the experiences and insights that the respondents had regarding the development of ecotourism in the Hutan Bambu Alu area. Structured interviews using a questionnaire were conducted on 64 visitor respondents, especially those who had visited the Hutan Bambu Alu. The selection of respondents was done by random sampling method. The questionnaire in the form of an online form was distributed via email and social media. Literature reviews was carried out by tracing several documents or reports and other references that contain important information relevant to this research needs.

\subsection{Data Analysis}

\subsubsection{Supply Potential Analysis}

The development of the potential of an area to become an object of tourist attraction requires an assessment of several elements needed as a potential supply. The analysis of the supply potential for Hutan Bambu Alu ecotourism used a scoring and weighting system according to the ODTWA Development Guidelines [5] and modified Ecotourism Planning Criteria [6]. The elements of the assessment of supply potential in this study include elements of attractiveness, accessibility, conditions around the area, facilities and infrastructure. The supply potential for the Hutan Bambu Alu ecotourism was assessed based on the following classifications (Attachment 2):
a. Low
: $1.195-1.939$
b. Moderate : $1.940-2.680$
c. High : $\geq 2.681$

The determination of the potential classification used the following formulation:

$$
\text { Interval }=\frac{\text { maximum } \text { weighted value }- \text { minimum weighted value }}{\text { the number of classifications }}
$$

\subsubsection{Demand Potential Analysis}

Analysis of the demand potential for ecotourism used the descriptive methods. The data obtained was tabulated, compiled and presented into important information based on visitor characteristics, preferences, frequency and number of visits, and visitors expectations

\subsubsection{Development Strategy Analysis for Bussiness Ecotourism in Hutan Bambu Alu}

The direction of the ecotourism development strategy in the Hutan Bambu Alu area was formulated using a SWOT analysis, Internal Factors Analysis Strategy (IFAS) and External Factors Analysis Srategy (EFAS). SWOT analysis identified various factors systematically to formulate a company strategy. This analysis is based on logic that maximizes the strengths and opportunities and minimizes weaknesses and threats [7], [8]. 
Formulation of alternative strategies for ecotourism development on Hutan Bambu Alu then proceed with the creation of a grand strategy matrix to determine the most suitable strategy for the development of Hutan Bambu Alu ecotourism. The steps to analyze the development strategy for new normal ecotourism on Hutan Bambu Alu namely:

1. Identified variables in IFAS and EFAS

2. Calculating the IFAS and EFAS values

3. Formulate a development strategy based on IFAS and EFAS

4. Determine the chosen strategy based on the assessment of IFAS and EFAS values and weights

\section{Results}

\subsection{Supply Potential of Hutan Bambu Alu Ecotourism}

Assessment of potential ecotourism attractiveness of Hutan Bambu Alu is carried out on 4 elements, namely attractiveness, accessibility, conditions around the area and facilities and infrastructure (Attachment 1). The results of the potential supply analysis show that the value of the potential offers for Hutan Bambu Alu ecotourism is 2,685 with a high classification (Table 1).

Table 1. The supply potential value of Hutan Bambu Alu Ecotourism

\begin{tabular}{llcc}
\hline No. & Element of Assessment & $\begin{array}{c}\text { Weighted } \\
\text { Value*) }\end{array}$ & Classification \\
\hline 1. & Attractiveness & 1.140 & High \\
2. & Accessibility & 400 & Moderate \\
3. & Conditions around the area & 1.025 & High \\
4. & Facilities and infrastructure & 120 & Moderate \\
& Total & 2.685 & High \\
\hline
\end{tabular}

*) Based on the criteria of ADO-ODTWA year 2003

From the four elements that were assessed, the elements of attractiveness and conditions around the area have a high potential value. In contrast to the elements of accessibility and facilities and infrastructure in the Hutan Bambu Alu ecotourism area which has a moderate classification. Road infrastructure in the Alu sub-district towards the Hutan Bambu Alu ecotourism area is still a major obstacle so that visitors take this into consideration. Some visitors even revealed that they were interested in frequently visiting the Hutan Bambu Alu area but were constrained by the road conditions they had reached, especially when entering the Alu Village area. The road is uphill, winding and the road is still a loose gravel road.

\subsection{Demand Potential for Hutan Bambu Alu Ecotourism}

The results of interviews through questionnaires show that the characteristics of visitors who have traveled to the Hutan Bambu Alu area are quite diverse (Picture 2). Based on age, the average visitor to the Hutan Bambu Alu is dominated by visitors aged 21-30 years. By profession, visitors to the Hutan Bambu Alu are quite a lot of students and university students. Generally they come in groups, at least 2-3 people in one visit. As many as $63 \%$ of visitors 
said that they often visited the Hutan Bambu Alu with up to 5 visits a year. They generally come from Polewali Mandar and Majene Regencies.
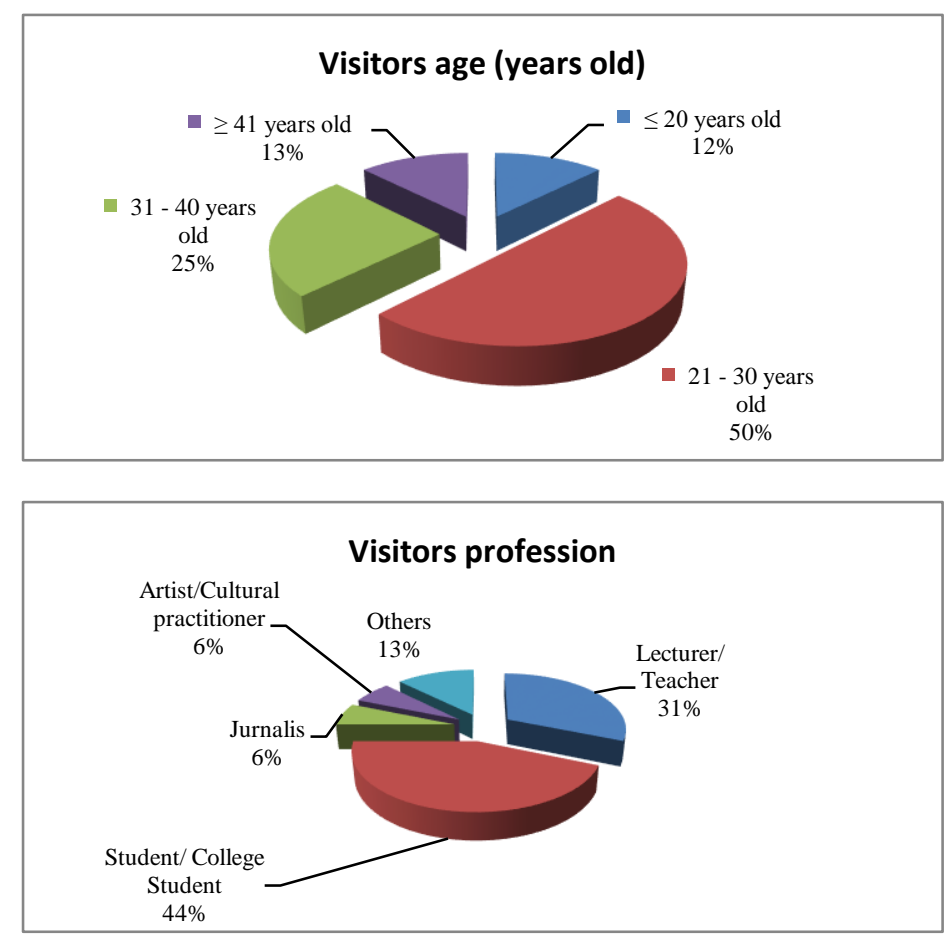

Figure 1. Characteristics of visitors in Hutan Bambu Alu

The results of the analysis of visitor preferences for the types of tourism that are preferred show that the types of tourism or activities that visitors like or expect are education and training (21\%), cultural tourism (19\%), photo hunting (14\%) and camping (14\%). In addition, there are also other types of tours or activities in the form of culinary tours, enjoying the scenery as well as historical tours and bird watching (Figure 2). 


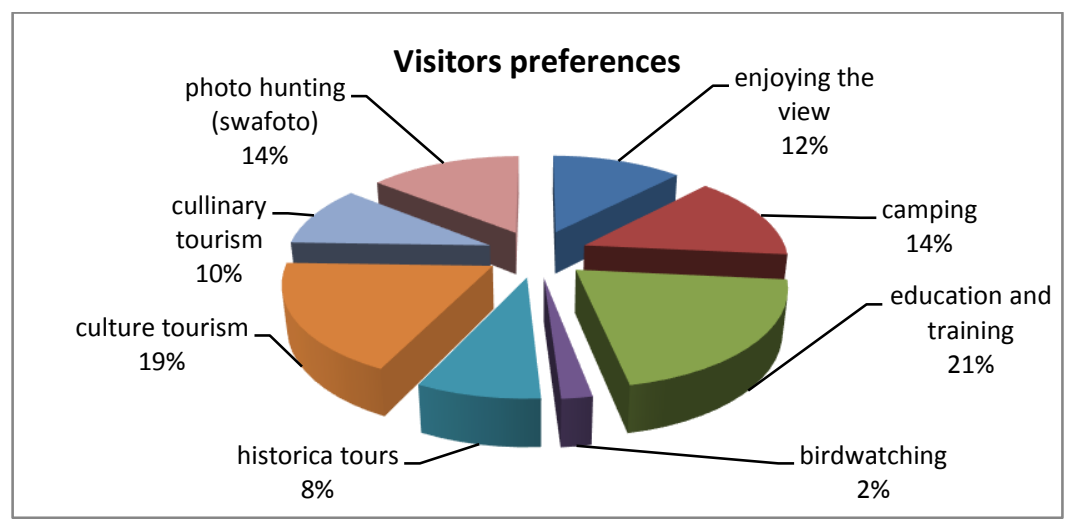

Figure 2. Visitor preferences on the type of tourism that is preferred or expected in the Hutan Bambu Alu

Through the interviews, visitors suggested that managers add tourist facilities while maintaining the preservation of the Hutan Bambu Alu area, developing new types of tourism according to Hutan Bambu Alu potential, improving governance and accessibility to the area, and vigorous promotion so that this area is known more widely to the outside of Sulawesi island.

\subsection{The Development Strategy of New Normal Ecotourism on Hutan Bambu Alu}

\subsubsection{Internal Factors Analysis Strategy (IFAS)}

The new normal ecotourism development strategy for Alu Bambu Forest was formulated by examining the relationship between identified internal and external factors. In internal factors, there are 7 strength factors of Hutan Bambu Alu that can be used as capital to develop this area into an ecotourism area. These factors are the high value of Hutan Bambu Alu ecotourism attraction, relatively good road conditions from the provincial capital, the existence of tourism potential other than nature in the form of historical, cultural and culinary tourism, the conditions around the area are suitable for developing tourist areas, clean water available, as a location for the development of research and service activities, and policy support. In other aspects, it is identified that there are still weaknesses of this area if it is to be developed into a new normal ecotourism area, namely the facilities and interpretation media with the new normal standard is still lacking, there is no detailed plan for the development of the new normal ecotourism business, there is no the guidance for managing visitors with new normal standard, product packaging of tourism is still lack and less varied, the potential for erosion during floods and fires during dry season, and the ecotourism management institutions of Hutan Bambu Alu that are considered not optimal (Table 2). 
Table 2. Matrix of identification and assessment of internal factors for Hutan Bambu Alu ecotourism development

\begin{tabular}{|c|c|c|c|c|}
\hline Code & Internal Factor & Bobot & Rating & Skor \\
\hline \multicolumn{4}{|c|}{ A. Strengths } & \multirow[b]{2}{*}{0.28} \\
\hline S1 & The value of ecotourism attractiveness is high & 0.07 & 4 & \\
\hline $\mathrm{S} 2$ & $\begin{array}{l}\text { Road conditions from the provincial capital are } \\
\text { relatively good }\end{array}$ & 0.06 & 4 & \\
\hline S3 & $\begin{array}{l}\text { Tourism potential other than natural, namely history, } \\
\text { culture and culinary }\end{array}$ & 0.07 & 4 & 0.28 \\
\hline S4 & $\begin{array}{l}\text { The condition around the area is suitable for the } \\
\text { development of a tourist area }\end{array}$ & 0.06 & 4 & 0.24 \\
\hline S5 & Clean water is available & 0.07 & 4 & 0.28 \\
\hline S6 & $\begin{array}{l}\text { Areas as locations for the development of research } \\
\text { and service activities }\end{array}$ & 0.07 & 3 & 0.21 \\
\hline \multirow[t]{2}{*}{ S7 } & Policy support & 0.07 & 4 & 0.28 \\
\hline & Total I & 0.47 & & 1.81 \\
\hline W1 & $\begin{array}{l}\text { B. Weaknesses } \\
\text { Interpretation facilities and means are still minimal } \\
\text { with the new normal standard still lacking }\end{array}$ & 0.10 & 4 & 0.4 \\
\hline W2 & $\begin{array}{l}\text { There is no detailed plan for the development of the } \\
\text { new normal ecotourism business }\end{array}$ & 0.07 & 3 & 0.21 \\
\hline W3 & $\begin{array}{l}\text { New normal visitor management guidelines do not yet } \\
\text { exist }\end{array}$ & 0.07 & 4 & 0.28 \\
\hline W4 & $\begin{array}{l}\text { The packaging of tourism products is still minimal } \\
\text { and less varied }\end{array}$ & 0.08 & 4 & 0.32 \\
\hline W5 & $\begin{array}{l}\text { Potential impact of erosion during floods and fire } \\
\text { during dry season }\end{array}$ & 0.09 & 4 & 0.36 \\
\hline \multirow[t]{3}{*}{ W6 } & The management institution is not optimal yet & 0.12 & 4 & 0.48 \\
\hline & Total II & 0.53 & & 2.05 \\
\hline & Total $(\mathrm{I}+\mathrm{II})$ & 1.00 & & \\
\hline
\end{tabular}

\subsubsection{Eksternal Factors Analysis Strategy (EFAS)}

On external factors, there are 5 factors of the strength of the Hutan Bambu Alu that can be used as capital to develop this area into an ecotourism area. These factors are the development of educational tourism for students, the increased need for recreation during the new normal, the potential for developing research locations, annual tourism events by the regional government and provincial government, and strong local institutions. In other aspects, there are identified threat factors that must be anticipated in the development of the new normal ecotourism business in the Hutan Bambu Alu area, namely the status of land ownership in the Hutan Bambu Alu area, there are other tourism objects (relatively similar), and shortcut access to community farm area (Table 3) 
Tabel 3. Matrix of identification and assessment of eksternal factors for Hutan Bambu Alu ecotourism development

\begin{tabular}{|c|c|c|c|c|}
\hline Code & Eksternal Factors & Bobot & Rating & Skor \\
\hline \multicolumn{5}{|c|}{ C. Opportunities } \\
\hline $\mathrm{O} 1$ & $\begin{array}{l}\text { Development of educational tours for } \\
\text { students }\end{array}$ & 0.12 & 4 & 0.48 \\
\hline $\mathrm{O} 2$ & $\begin{array}{l}\text { Increased need for recreation during the new } \\
\text { normal }\end{array}$ & 0.12 & 4 & 0.48 \\
\hline $\mathrm{O} 3$ & $\begin{array}{l}\text { The potential for developing research } \\
\text { locations }\end{array}$ & 0.08 & 4 & 0.32 \\
\hline $\mathrm{O} 4$ & $\begin{array}{l}\text { Annual tourism events by local and } \\
\text { provincial governments }\end{array}$ & 0.14 & 4 & 0.56 \\
\hline O5 & Strong the local institutions & 0.17 & 5 & 0.85 \\
\hline & Total I & 0.63 & & 2.69 \\
\hline $\mathrm{T} 1$ & $\begin{array}{l}\text { D. Threats } \\
\text { Status of land ownership in the Hutan Bambu } \\
\text { Alu area }\end{array}$ & 0.20 & 4 & 0.8 \\
\hline $\mathrm{T} 2$ & $\begin{array}{l}\text { There are the other tourism objects (relatively } \\
\text { similar) }\end{array}$ & 0.07 & 3 & 0.21 \\
\hline \multirow[t]{2}{*}{$\mathrm{T} 3$} & $\begin{array}{l}\text { HBA area as shortcut access to community } \\
\text { gardens }\end{array}$ & 0.10 & 4 & 0.4 \\
\hline & $\begin{array}{r}\text { Total II } \\
\text { Total (I + II) }\end{array}$ & $\begin{array}{l}0.37 \\
1.00\end{array}$ & & 1.41 \\
\hline
\end{tabular}

Based on the identified internal and external factors above, there are 4 possible formulations of alternative strategies for developing the new normal ecotourism business in Hutan Bambu Alu [7], [8]. The four strategies describe the relationship with each other among the identified factors (Table 4).

Table 4. The formulation of development strategy for the new normal ecotourism business on Hutan Bambu Alu

\begin{tabular}{|c|c|c|}
\hline \multirow[t]{3}{*}{ Internal } & \multirow{3}{*}{$\begin{array}{l}\text { Strengths: } \\
\text { 1. The value of ecotourism } \\
\text { attractiveness is high } \\
\text { 2. Road conditions from the } \\
\text { provincial capital are relatively } \\
\text { good } \\
\text { 3. Tourism potential other than } \\
\text { natural, namely history, culture } \\
\text { and culinary } \\
\text { 4. The condition around the area is } \\
\text { suitable for the development of } \\
\text { a tourist area } \\
\text { 5. Clean water is available }\end{array}$} & $\begin{array}{l}\text { Weaknesses: } \\
\text { 1. Interpretation facilities and } \\
\text { means are still minimal with } \\
\text { the new normal standard still } \\
\text { lacking } \\
\text { 2. There is no detailed plan for } \\
\text { the development of the new } \\
\text { normal ecotourism business }\end{array}$ \\
\hline & & $\begin{array}{l}\text { 3. New normal visitor } \\
\text { management guidelines do not } \\
\text { yet exist }\end{array}$ \\
\hline & & $\begin{array}{l}\text { 4. The packaging of tourism } \\
\text { products is still minimal and }\end{array}$ \\
\hline
\end{tabular}


6. Areas as locations for the development of research and service activities

7. Policy support

Opportunities:

1. Development of educational tours for students

2. Increased need for recreation during the new normal

3. The potential for developing research locations by local and provincial governments

5. Strong the local institutions
4. Annual tourism events
SO, The strength-opportunity strategy is creating a strategy that uses strength to take advantage of opportunities :

1. Incorporate Hutan Bambu Alu ecotourism development in regional priority tourism development

2. Management of the new normal ecotourism area

3. Make product diversification

4. Promotion of product marketing through schools

5. Development of educational ecotourism products
5. less varied

6. Potential impact of erosion during floods and fire during dry season

7. The management institution is not optimal yet

WO, Weakness-opportunity strategy is creating a strategy that minimizes weaknesses to take advantage of opportunities :

1. Creating a visitor management design with the new normal standard

2. Providing ecotourism facilities and infrastructure

3. Strengthen the marketing mix

4. Improve the competence of human resources managing new normal ecotourism through education and training

5. Developing an ecotourism area based on collaborative research and disaster mitigation

6. Arrangement of attraction locations based on sensitivity of the area

ST, The strength-threat strategy is

WT, The weakness-threat strategy is creating a strategy to minimize weaknesses and avoid threats: to overcome threats :

1. Setting the time of the visit ALU area

2. There are the other tourism objects (relatively similar)

3. HBA area as shortcut access to community gardens
2. Security and maintenance of the area

3. Product diversification that is unique and different from other tourist areas

4. Development of tourism products that strengthen the resilience of the Hutan Bambu Alu ecotourism area
1. Focus on developing a more attractive appeal

2. Involve the community including land owners in the management of the Hutan Bambu Alu ecotourism area

3. Provide a means of educational interpretation of the importance of conservation and environmental preservation

4. Providing conservation and environmental education to the surrounding community

5. Management of the area in a transparent and accountable manner 
Based on the grand strategy analysis, internal factors have a value of -0.24 (negative) and external factors have a value of 1.28 (positive) [Table 5]. That is, the suitable strategy for the development of new normal ecotourism bussiness in Hutan Bambu Alu is in quadrant II (stability), namely to minimize weaknesses to take advantage of opportunities (Picture 3).

Table 5. The value and position of internal and external faktor on the grand strategy matriks

\begin{tabular}{lclc}
\hline \multicolumn{1}{c}{ Internal Factors } & $\begin{array}{c}\text { The Value of } \\
\text { Internal Factors }\end{array}$ & Eksternal Factors & $\begin{array}{c}\text { The value of External } \\
\text { Factors }\end{array}$ \\
\hline Strengths & 1.81 & Opportunities & 2.69 \\
Weaknesses & 2.05 & $\begin{array}{l}\text { Threats } \\
\text { Opportunities - }\end{array}$ & 1.41 \\
Strengths - weaknesses & -0.24 & Threats & 1.28 \\
Position & X-axis; negative & Position & Y-axis; positive \\
\hline
\end{tabular}

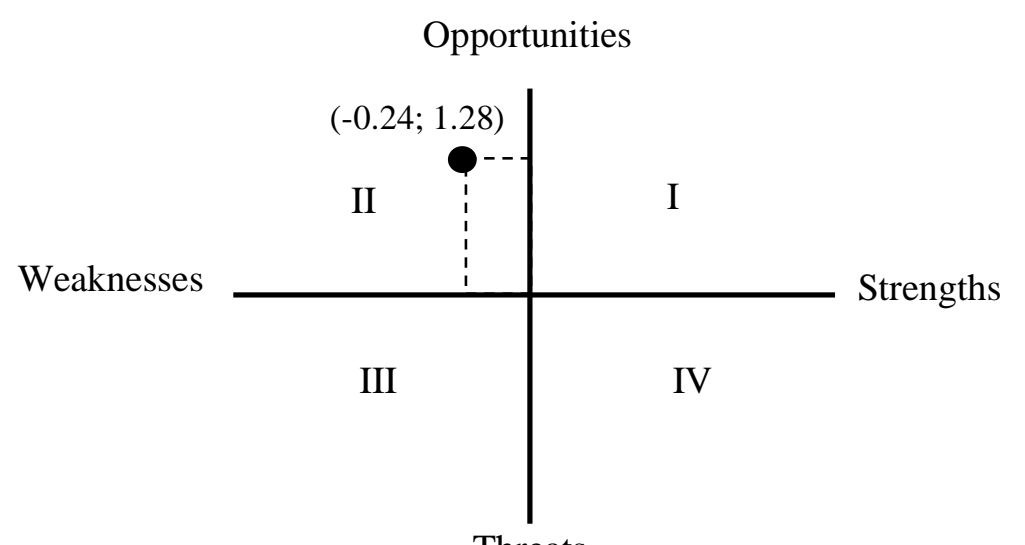

Threats

Figure 3. Grand strategy of development of new normal ecotourism bussiness in Hutan Bambu Alu

\section{Discussion}

Based on the results of the analysis that considered the internal and external factors of the Hutan Bambu Alu area, the development of this tourist destination requires a strategy with an approach to minimize weaknesses to take advantage of opportunities. This strategy consists of:

1. Creating a visitors management design with the new normal standard

2. Providing the ecotourism faciities and infrastructure

3. Strengthen the marketing mix

4. Improve the competence of human resources managing new normal ecotourism through education and training

5. Developing an ecotourism area based on collaborative research and disaster mitigation 


\section{Arrangement of attraction locations based on regional sensitivity}

The covid-19 pandemic also drastically reduced the number of visitors to the Hutan Bambu Alu. In fact, from mid-March to early May 2020, there were no visitors at all, even though it was for research purposes, as revealed by one respondent who was conducting research on bamboo in the Hutan Bambu Alu. The Alu Village Government does impose visit restrictions for outsiders or newcomers who will enter their village territory. The goal is to prevent the spread of covid-19 according to government directions. The developing pandemic situation gave birth to the concept of a new order of life with a new normal being a consideration so that the development of the Hutan Bambu Alu ecotourism requires a visitor management design with a new normal ecotourism standard. For example, by limiting the number of visits, setting the concentration of visitor activity, setting the time of visits, providing facilities or media of interpretation and implementing health protocols in an orderly manner for every visitor who comes. According to Kastolani and Rahmafitria (2015), visitor arrangements can be carried out, including by limiting access to locations and attractions, implementing decentralization of visitor facilities and activities, developing environmental education-based interpretation facilities [9].

Facilities and infrastructure especially roads need special attention from the government. The most important road conditions receive priority repair and improvement of the road quality, namely road infrastructure around the gateway to Alu Village and to Hutan Bambu Alu area. These two location points are also important icons in the Hutan Bambu Alu ecotourism.

The competence of human resources in managing the Hutan Bambu Alu ecotourism business needs to be improved through education and training. Currently, through the activities of the Partnership Village Development Program (PPDM) of the Universitas Sulawesi Barat, the human resources managing the Hutan Bambu Alu ecotourism have received training in ecotourism management in the new normal period. However, this training still requires further training to ensure that the management human resources really understand and are able to manage the area according to the principles of ecotourism. These principles include minimizing negative impacts on nature and culture, educating visitors about the importance of conservation, maximizing economic benefits, especially for communities living around tourist areas, and emphasizing the importance of managing tourism areas responsibly [10]. Another type of training that has been attended is a workshop on the use of IT in online ecotourism product marketing. The manager hopes that this training can make a real contribution to increasing the number of visits to the Hutan Bambu Alu. Quality human resource management in the tourism sector plays a role in improving economic performance and competitiveness of the tourism market [11].

The next strategy relates to the history of disasters that have occurred in Alu Village. Even in 2019, several tourist facilities that had been built in the Hutan Bambu Alu area were damaged and lost due to flooding. Spatially, the position of the Hutan Bambu Alu is surrounded by the Mandar River which is included in the Mandar watershed area in West Sulawesi. The implication is that the Hutan Bambu Alu requires structuring an ecotourism landscape that minimizes the impact of disaster risks on tourism facilities and activities in it. Of course, the visitor safety factor is a top priority. Destinations with areas that function as agricultural land are the most affected due to the estimated increase in temperature and increased rainfall [12]. Apart from being surrounded by rivers, the Hutan Bambu Alu is surrounded by community agricultural land so that the arrangement of its ecotourism landscape needs to consider the area's sensitivity to natural disasters (floods and landslides). 
For example, tourist attraction activities are focused on areas that have a low level of sensitivity so that visitors can enjoy tourist activities comfortably and safely.

\section{Conclusion}

The main supply and support element of the Hutan Bambu Alu ecotourism business had a high category so that it was feasible and suitable to be developed into a new normal ecotourism business. The selected strategy for developing a new normal ecotourism business is to minimize weaknesses to take advantage of opportunities, namely designing visitor management with new normal standards, providing ecotourism facilities and infrastructure, strengthening the marketing mix, enhancing the competence of human resources for new normal ecotourism managers through education and training, structuring ecotourism landscapes based on areas sensitivity, and developing ecotourism areas based on collaborative research and disaster mitigation).

\section{References}

[1] [Kemenparekraf] Kementerian Pariwisata dan Ekonomi Kreatif RepublikIndonesia: Siaran Pers: Penurunan Kunjungan Wisman Ke Indonesia Akibat Pandemi Covid-19 Sesuai Perkiraan. Senin, 4 Mei 2020. Kementerian Pariwisata dan Ekonomi Kreatif Republik Indonesia, Jakarta, (2020).

[2] Amin, A.RafiqaPrawira, M. R.and Hadijah, S.: Program Pengembangan Desa Mitra (PPDM) Untuk Mewujudkan Desa Ekowisata Bambu Alu Di Desa Alu, Kab. Polewali Mandar, Sulawesi Barat, Abdimas Todopuli J. Pengabdi. pada Masy., vol. 1 , no. 1, pp. 28-40, (2019).

[3] Utama, I. G. B. . and Junaedi, I. W. .:Agrowisata sebagai Pariwisata Alternatif Indonesia: Solusi Masif Pengentasan Kemiskinan. Yogyakarta: Deepublish Publisher, (2019).

[4] Muntasib, E. K. .: Peluang Ekowisata Untuk Periode New Era Covid 19, ( 2020).

[5] Dirjen PHKA:Pedoman Analisis Daerah Operasi Obyek Daya Tarik Wisata Alam (ADOODTWA). Bogor (ID): Dirjen Perlindungan Hutan dan Konservasi Alam, (2003).

[6] Damanik, J. and Weber, H. F.:Perencanaan Ekowisata: Dari Teori ke Aplikasi. Yogyakarta: Penerbit ANDI, (2006).

[7] Rangkuti, F.:Analisis SWOT: Teknik membedah kasus bisnis - reorientasi konsep perencanaan startegis untuk menghadapi abad 21. Jakarta: Gramedia Pustaka Utama, (2006).

[8] Assauri, S.:Strategic Management: Sustainable Competitive Adventages. Jakarta (ID): PT Rajagrafindo Persada, (2013).

[9] Kastolani, W. and Rahmafitria, F.: Model Pengaturan Pengunjung Pada Kawasan Wisata Alam Pegunungan Dengan Fungsi Lindung Dan Intensitas Wisata Tinggi, Spat. Wahana Komun. dan Inf. Geogr., vol. 14, no. 2, pp. 21-29, (2015).

[10] Wood, M. E.:Principles, Practices \& Policies for Sustainability, First Edit. France: United Nations Publications, (2002).

[11] Herman, S.:Management of Human Resources in Tourism. Croatia: Faculty of Economics in Osijek, Republic of Croatia. University Specialist of Economy (univ.spec.oec.), 
(2015).

[12] Hidalgo, H. A.: Vulnerability Assessment Of Agri-Ecotourism Communities As Influenced By Climate Change, Int. J. Adv. Sci. Eng. Inf. Technol., vol. 5, no. 6, pp. 379-386, (2015). 
Attachment 1. Assessment of Supply Potential for New Normal Ecotourism in Hutan Bambu Alu

The attractiveness of Hutan Bambu Alu

\begin{tabular}{clccc}
\hline No. & \multicolumn{1}{c}{ Sub unsur } & Weight & Nilai & Score \\
\hline 1 & The beauty of nature & 6 & 30 & 180 \\
2 & The uniqueness of natural resources & 6 & 15 & 90 \\
3 & Many types of natural resources are prominent & 6 & 25 & 150 \\
4 & The integrity of natural resources & 6 & 30 & 180 \\
5 & Natural resource sensitivity & 6 & 10 & 60 \\
6 & Types of nature tourism activity & 6 & 25 & 150 \\
7 & Cleanliness of the area & 6 & 30 & 180 \\
8 & Area security & 6 & 25 & 150 \\
& & & Total & 1,140 \\
& & & Classification & High
\end{tabular}

Accecibilities to Hutan Bambu Alu area

\begin{tabular}{llccc}
\hline NO & \multicolumn{1}{c}{ Sub unsur } & Weight & Value & Score \\
\hline 1 & $\begin{array}{l}\text { The condition and distance of the roa from the } \\
\text { provincial capital } \\
>225 \mathrm{Km}\end{array}$ & 5 & 20 & 100 \\
2 & $\begin{array}{l}\text { International/domestic air gateway } \\
\text { Makassar }\end{array}$ & 5 & 35 & 175 \\
3 & $\begin{array}{l}\text { Travel time from the provincial capital } \\
\text { The frequency of the vehicle from the } \\
\text { information center to the tourist attraction }\end{array}$ & 5 & 15 & 75 \\
& & 5 & 10 & 50 \\
& & Classification & Moderate \\
\hline
\end{tabular}

Conditions around the Hutan Bambu Alu area

\begin{tabular}{clrrc}
\hline NO & \multicolumn{1}{c}{ Sub unsur } & Weight & Value & Score \\
\hline 1 & Spatial distribution of the object or attractions & 5 & 30 & 150 \\
2 & Unemployment rate & 5 & 25 & 125 \\
3 & People's livelihoods & 5 & 20 & 100 \\
4 & Movement space for visitors & 5 & 30 & 150 \\
5 & Education & 5 & 25 & 125 \\
6 & Soil fertility & 5 & 20 & 100 \\
\hline
\end{tabular}




\begin{tabular}{llrrr}
\hline & Natural resources & 5 & 25 & 125 \\
8 & $\begin{array}{l}\text { Community response to the development of } \\
\text { Hutan Bambu Alu ecotourism }\end{array}$ & 5 & 30 & 150 \\
& & $\begin{array}{r}\text { Total } \\
\text { Classification }\end{array}$ & High \\
\hline
\end{tabular}

Facilities and Infrastructure of ecotourism in Hutan Bambu Alu

\begin{tabular}{clcccc}
\hline No. & & Sub Unsur & Weight & Value & Score \\
\hline 1 & Facilities & 3 & 15 & 45 \\
2 & Infrastructure & 3 & 25 & 75 \\
& & & Total & 120 \\
& & & Classification & Moderate \\
\hline
\end{tabular}

Attachment 2. Classification of supply potential assessment for Ecotourism in Hutan Bambu Alu

\begin{tabular}{llccc}
\hline \multicolumn{2}{c}{ Alu } & \multicolumn{3}{c}{ Classification of Assessment } \\
\cline { 3 - 5 } No. & \multicolumn{1}{c}{ Unsur Penilaian } & Rendah & Sedang & Tinggi \\
\cline { 3 - 5 } 1. & Attractiveness & $480-800$ & $801-1.120$ & $1.121-1.440$ \\
2. & Accecibility & $205-337$ & $338-468$ & $469-600$ \\
3. & Condition around the area & $450-700$ & $701-950$ & $951-1.200$ \\
4. & Facilities and infrastructure & $60-100$ & $101-140$ & $141-180$ \\
\hline & Total & $1,195-1,939$ & $1,940-2,680$ & $2,681 \leq$ \\
\hline
\end{tabular}

